\title{
Morphological and Molecular Identification of Three Ceriodaphnia Species (Cladocera: Daphniidae) from Australia
}

\author{
Pranay Sharma \\ School of Earth and Environmental Sciences, University of Adelaide, Adelaide, SA 5000, Australia \\ Correspondence should be addressed to Pranay Sharma; pranay.sharma@adelaide.edu.au
}

Received 6 August 2014; Revised 14 October 2014; Accepted 16 October 2014; Published 14 December 2014

Academic Editor: Lorena Rebecchi

Copyright (C) 2014 Pranay Sharma. This is an open access article distributed under the Creative Commons Attribution License, which permits unrestricted use, distribution, and reproduction in any medium, provided the original work is properly cited.

\begin{abstract}
Australian Ceriodaphnia (Cladocera: Daphniidae) are examined using morphological attributes and two mitochondrial DNA (COI and 16s) and one nuclear DNA (28s) gene fragments to differentiate the species. The sequence data supports the existence of three species, that is, C. dubia, one reinstated species C. spinata Henry, 1919, and one new species C. sp. 1. Morphological characteristics were also able to accurately separate the three species. Furthermore, genetic analysis of COI sequences from Ceriodaphnia supported three clades. The high degree of correlation between morphological and molecular identification in this study indicates that mitochondrial markers, COI and 16s, are appropriate molecular markers for species discrimination and identification of Ceriodaphnia.
\end{abstract}

\section{Introduction}

Ceriodaphnia Dana, 1853 (Cladocera: Daphniidae), displays little diversification in terms of species richness and morphological disparity, with the genus currently comprising 14 "valid" species worldwide, predominantly based on morphology [1]. In addition, there are 21 species inquirenda and 24 species that are probably junior synonyms of previously described species [1]. There is limited morphological and genetic evidence to support this proliferation of the large number of proposed names. According to Smirnov and Timms (1983) [2], there are only five Ceriodaphnia species from Australia which includes one beaked species ('beak' = a rostral projection) i.e. C. cornuta Sars, 1885, and four nonbeaked species C. dubia Richard, 1894, C. laticaudata Müller, 1867, C. quadrangula (Müller, 1785) and C. rotunda Sars, 1862. One further, non-beaked species, C. pulchella Sars, 1862, has been recorded since [3]. In addition to these, two more non-beaked species, C. planifrons Smith, 1909 and C. spinata Henry, 1919 were re-instated by Berner [4], thereby increasing the total number of recorded species from Australia to eight.

The literature on Ceriodaphnia sp. generally points towards the absence of divergent morphological characters for this group. Additionally, the historical taxonomic descriptions are incomplete and primarily focused on the head, antennule, antennae, postabdomen, carapace, reticulation, and rarely trunk appendages of Ceriodaphnia. Where morphological evidence is unclear, molecular techniques can be used to improve our understanding of taxonomic divergence and speciation. Barnett et al. [5] emphasised that genetics has become an increasingly important parameter in the classification and identification of organisms in comparison to more traditional morphological descriptors. The success of using Cytochrome Oxidase I (COI) gene region to distinguish species from a range of taxa and to reveal cryptic species has been remarkable. This method of matching unknown molecular sequences to species, however, is only effective for those which have been studied extensively using a variety of characters such as morphology, reproduction, ecology, and geographical distribution that have been well documented by researchers [6].

For example, the taxonomy of Daphnia has been the subject of intense investigations for over a century owing to its intraspecific variation. The gradual increase in the species discovery rate of Daphnia is due to the succession of molecular genetics from traditional taxonomy (see Supplementary Figure 1 in Supplementary Material available online at http://dx.doi.org/10.1155/2014/258134).

The advancement in molecular techniques, especially the introduction of allozyme technique to study interspecific 
hybridisation in D. carinata by Hebert [7], followed by DNA barcoding in 1994, saw a steady rise in species discovery, especially of cryptic species. Similarly, for other species of Daphnia, such as D. pulex where traditional taxonomy often resulted in grouping phenotypically similar species, genetic techniques have revealed a number of new species [8-15]. The study by Colbourne et al. [16] provided draft genomes of 200 mega bases for D. pulex, helping to understand environmental influences on gene function.

The objective of the present study was to consider all available data, morphological and molecular (mitochondrial and nuclear genes) of the valid eight Ceriodaphnia species, from Australia, and to clarify the taxonomical position of selected Australian Ceriodaphnia species.

\section{Materials and Methods}

Sixty female specimens of Ceriodaphnia (excluding C. cornuta, Sars, 1890, a beaked variety) preserved in $70 \%$ ethanol from 11 sampling sites in Australia (see Table 1) were used for morphological and molecular analyses.

2.1. Morphological Analysis. Eggs and young adults from a total of 60 ovigerous females were teased out from the brood chamber and stored in new $0.5 \mathrm{~mL}$ microtubes containing $90 \%$ denatured ethanol for genetic analysis. The rest of the body was transferred onto a slide containing Polyvinyl Alcohol (PVA) and left in a Greiner petri dish for $24 \mathrm{~h}$. After 24 h equilibration, the specimen was dissected using tungsten needles and examined under a compound microscope for further detailed morphological analysis. Digital photographs were taken using Olympus BX51 microscope under high resolution using polarizing light and composite line drawings were made from these photographs for different parts of the specimen. Inbuilt imaging software Image $J$ was used to calculate sizes of body parts. Ceriodaphnia species were identified morphologically using taxonomic keys of Shiel [3] and Kořinek [17]. Slide mounted Ceriodaphnia collections from Australian Museum, Sydney, Australia (AMS); Natural History Museum, University of Ohio, Norway (NHMUO); Naturkunde-Museum, Coburg, Germany (NMCL) museums were also examined and their morphological characteristics were compared with the Australian Ceriodaphnia specimens used during this study.

In addition to light microscopy, specimens were prepared for SEM as described in Berner and Rakhmatullaeva [18, 19]. The specimens were sputter-coated with gold and were examined under a Philips XL 20 SEM with an accelerating voltage of 10-20 KV, working distance between 9.6 and $14 \mathrm{~mm}$ and spot size at $3 / 4$.

2.2. DNA Extraction, PCR, and Sequencing. DNA extraction was performed on eggs or young adults with DNeasy Tissue kit (Qiagen Inc.) according to the manufacturer's instructions.

Polymerase chain reaction was subsequently utilized to amplify the COI gene with Folmer primer pair (LCO 1490 and HCO 2198) [20]. Each $50 \mu \mathrm{L}$ PCR reaction consisted of
$5 \mu \mathrm{L}$ of genomic DNA template, $3 \mu \mathrm{L}$ of $50 \mathrm{mM} \mathrm{MgCl}_{2}, 5 \mu \mathrm{L}$ of $10 \mathrm{x}$ Buffer, $1.5 \mu \mathrm{L}$ of each primer, $1 \mu \mathrm{L}$ of $10 \mu \mathrm{M}$ dNTP's, $0.24 \mu \mathrm{L}$ of Taq platinum polymerase, and $32.76 \mu \mathrm{L}$ of DNA free Milli-Q water. PCR thermocycling was performed under the following conditions: 1 cycle of $2 \mathrm{~min} 30 \mathrm{sec}$ at $94^{\circ} \mathrm{C} ; 5$ cycles each of $94^{\circ} \mathrm{C}$ for $35 \mathrm{sec}, 48^{\circ} \mathrm{C}$ for $40 \mathrm{sec}$, and $72^{\circ} \mathrm{C}$ for $1 \mathrm{~min}$; followed by $35 \mathrm{cycles}$ each of $94^{\circ} \mathrm{C}$ for $30 \mathrm{sec}, 56^{\circ} \mathrm{C}$ for $40 \mathrm{sec}$, and $72^{\circ} \mathrm{C}$ for $1 \mathrm{~min}$; finishing with a step of $72^{\circ} \mathrm{C}$ for $10 \mathrm{~min}$.

16s rDNA mitochondrial genes were amplified using 16s1 5'-CCGGAATTCCGCCTGTTTATCAAAAACA-3' and 16s2 $5^{\prime}$-CCCAAGCTTCTCCGGTTTGAACTCAGAT$3^{\prime}$ (modified Simon et al. 1994) [21] primers. PCR reaction as mentioned above. PCR thermocycling was performed under the following conditions: 1 cycle of $2 \mathrm{~min} 30 \mathrm{sec}$ at $94^{\circ} \mathrm{C} ; 5$ cycles each of $94^{\circ} \mathrm{C}$ for $35 \mathrm{sec}, 60^{\circ} \mathrm{C}$ for $40 \mathrm{sec}$, and $72^{\circ} \mathrm{C}$ for $1 \mathrm{~min}$; followed by 35 cycles each of $94^{\circ} \mathrm{C}$ for $30 \mathrm{sec}, 64^{\circ} \mathrm{C}$ for $40 \mathrm{sec}$, and $72^{\circ} \mathrm{C}$ for $1 \mathrm{~min}$; finishing with a step of $72^{\circ} \mathrm{C}$ for $10 \mathrm{~min}$. For $28 \mathrm{~s}$ rRNA, the primers used for amplification were $28 \mathrm{~s} 15^{\prime}$-CCCGCTGAATTTAAGCATAT- $3^{\prime}$ and $28 \mathrm{~s} 25^{\prime}$ TAGATGGTTCGATTAGTCTTTCGC-3' [22]; PCR thermo cycling was performed under the following conditions: 1 cycle of $2 \mathrm{~min} 30 \mathrm{sec}$ at $94^{\circ} \mathrm{C} ; 5 \mathrm{cycles}$ each of $94^{\circ} \mathrm{C}$ for $35 \mathrm{sec}, 56^{\circ} \mathrm{C}$ for $40 \mathrm{sec}$, and $72^{\circ} \mathrm{C}$ for $1 \mathrm{~min}$; followed by $35 \mathrm{cycles}$ each of $94^{\circ} \mathrm{C}$ for $30 \mathrm{sec}, 62^{\circ} \mathrm{C}$ for $40 \mathrm{sec}$, and $72^{\circ} \mathrm{C}$ for $1 \mathrm{~min}$; finishing with a step of $72^{\circ} \mathrm{C}$ for $10 \mathrm{~min}$.

The PCR products were run in $2 \%$ agarose gels containing $10 \mu \mathrm{L}$ of SYBR Safe DNA gel stain (Invitrogen Inc.) for 2 to $4 \mathrm{~h}$ at 80 to $100 \mathrm{~V}$ and visualized using UV-transillumination. When amplified bands were sharp and clean, in few cases where there were double bands, the target band was cut and purified from the agarose gel using QIAquick Gel Extraction Kit to avoid contamination from any other nonspecific bands. PCR purified products were cycle-sequenced using BigDye Sequencing kit Terminator 3.1 (Applied Biosystems) for both forward and reverse directions. Cycle-sequencing reactions were carried out in $10 \mu \mathrm{L}$ total volume, containing 1 to $3 \mu \mathrm{L}$ of purified PCR product, $3.5 \mu \mathrm{L}$ of sequencing buffer, $1 \mu \mathrm{L}$ of Big Dye Terminator, and $0.5 \mu \mathrm{L}$ of forward and reverse primer with total volume made up to $10 \mu \mathrm{L}$ using DNA free Milli-Q water. The sequencing thermal cycle consisted of 1 cycle of $1 \mathrm{~min}$ at $95^{\circ} \mathrm{C}$, followed by 25 cycles of $95^{\circ} \mathrm{C}$ for $15 \mathrm{sec}, 50^{\circ} \mathrm{C}$ for $10 \mathrm{sec}$, and $60^{\circ} \mathrm{C}$ for $4 \mathrm{~min}$, with final overnight incubation at $25^{\circ} \mathrm{C}$. The sequencing product was then purified using Millipore TM384-SEQ Filter plates and 1x Tris Buffer. The purified PCR products along with primers (LCO1490 and HCO2198) were sent to the Australian Genome Research Facility Ltd., Australia, and Macrogen Inc., Republic of Korea, for sequencing on the Applied Biosystems 3730xl capillary sequencers.

2.3. Phylogenetic Analysis Based on cmtDNA. Both forward and reverse DNA sequences were analyzed and aligned using Clustal W application implemented in software Bioedit ver. 7.0.0. [23], with gap open penalty set to 100, so gaps become less frequent. The protein coding sequences of COI were translated into amino acids using MEGA ver. 5.05 [24], to check for stop codons. Phylogenetic analysis was conducted using Mega, PhyML, and Mr. Bayes on both 


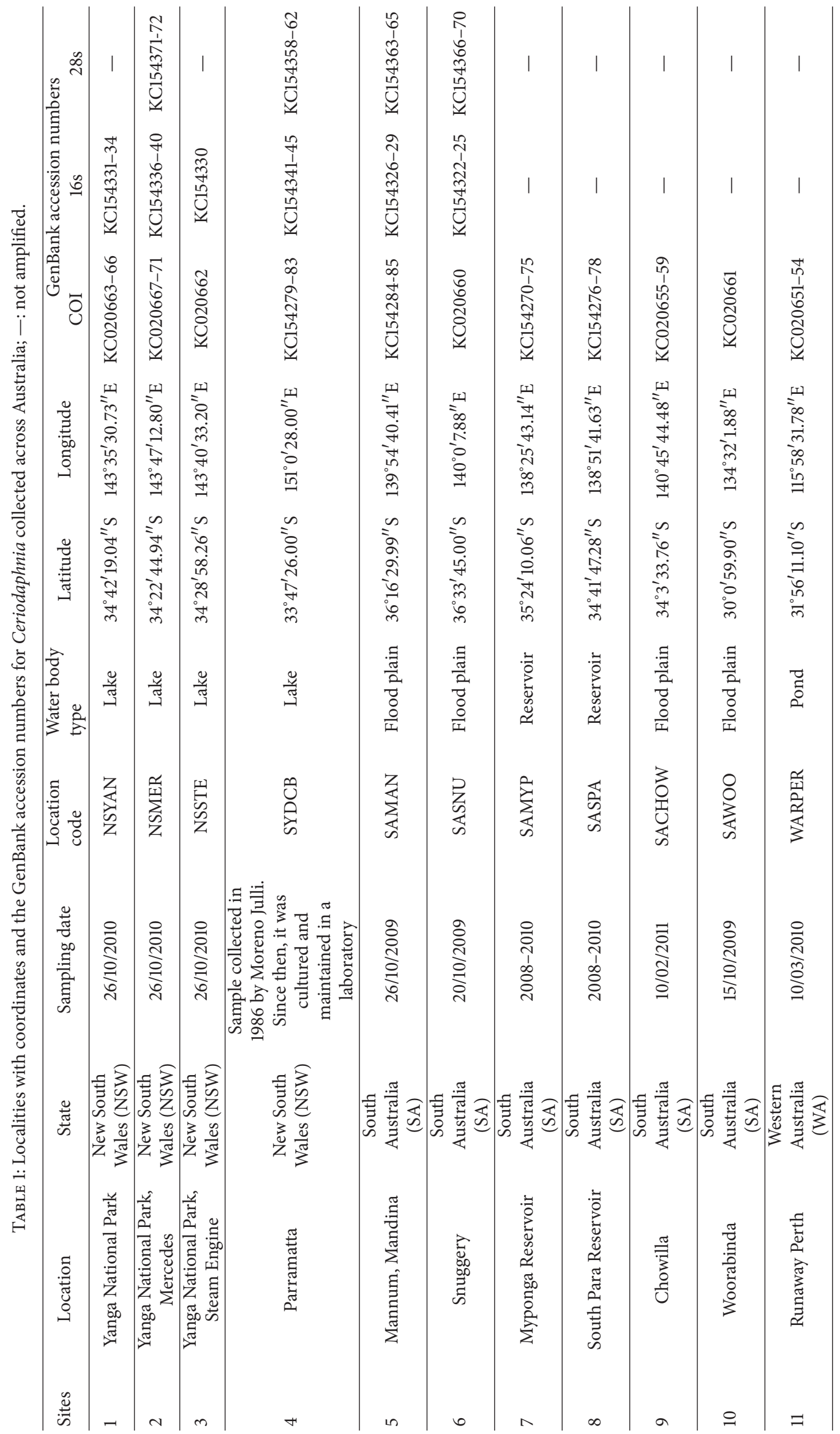


separate and concatenated mitochondrial $(\mathrm{cmtDNA}=16 \mathrm{~s}+$ COI, 1185 bp) datasets. Phylogenetic trees were inferred by Neighbour-Joining (NJ), Maximum Likelihood (ML), and Bayesian Inference (BI). The best fit models of nucleotide substitution were selected using the Model Generator [25]; ML tree was constructed using PhyML ver. 3.0 [26]; branch support values were estimated using 100 bootstrap replicates. All other parameters were set to their default values. BI analysis was performed using Mr. Bayes ver. 3.1.2 [27]. NJ trees were constructed using MEGA ver. 5.05 and Kimura 2parameter (K2P) distance with complete deletion of missing information. Four substitution rate categories were considered while gamma shape parameters, transition/transversion ratios, and nucleotide frequencies were estimated from the data. Proportions of invariable sites were set according to values given by models obtained from Model Generator with 100 bootstrap replications. Alignment gaps were treated as unknown characters. For Bayesian analysis the Markov Chain Monte Carlo chains were run for $10^{6}$ generations and trees were sampled every 100 generations. Of the generated trees, the first $25 \%$ were eliminated as burn-in. Runs were checked for convergence and normal distribution in Tracer ver. 1.5 [28].

The sequences are deposited in GenBank under accession numbers KC154268-KC154287; KC020651-KC020671 for COI gene fragments; KC154322-KC154345 for 16s gene fragments; and KC154358-KC154372 for 28s gene fragments.

COI gene sequences for Ceriodaphnia used in this study are compared with published COI sequences available from GenBank (number of taxa =124; number of haplotypes $=31$; base pair length $\geq 500$ ), most of which originated from North American taxa [29].

Abbreviations used for museum collections are as follows:

$$
\begin{aligned}
& \text { AMS = Australian Museum Sydney, Australia; } \\
& \text { NHMUO = Natural History Museum, University of } \\
& \text { Oslo, Norway; } \\
& \text { NMCL = Naturkunde-Museum, Coburg, Germany; } \\
& \text { SAM = South Australian Museum, Australia. }
\end{aligned}
$$

\section{Results}

3.1. Descriptions of Species Based on Morphological Characteristics. Ten key morphological characteristics were used in the present study and are summarized in Table 2. Accordingly, of the Australian female specimens examined, the following three species were identified: C. dubia, C. sp. 1, and C. spinata.

3.1.1. Genus Ceriodaphnia Dana, 1853. Ceriodaphnia Dana, 1853: 1273; Müller, 1868: 125; Schoedler, 1877: 19; Winchell, 1883: 35; Stingelin, 1896: 211; Lilljeborg, 1900: 183; Lilljeborg, 1901: 675; Smith, 1909: 80; Sars, 1916: 315; Henry, 1922: 32.

Type Species. Ceriodaphnia quadrangular (O. F. Müller, 1785).

Diagnosis. Valves of the carapace ending in a posterior angle or a short spine. Head small, depressed and separated from body by a deep cervical groove. Carapace marked by a polygonal pattern. Antennules in female not freely movable. Ocellus always present. Ephippium triangular, containing more than one egg.

3.1.2. Ceriodaphnia dubia Richard, 1894 (Figures 6-8). Ceriodaphnia dubia Richard, 1894: 570; Delachaux, 1917: 80; Sars, 1916: 317; Berner, 1986: 16; Greenwood et al. 1991: 285.

Syn.: Ceriodaphnia affinis Lilljeborg, 1901: 675.

Syn.: Ceriodaphnia limicola Ekman, 1900: 70.

Syn.: Ceriodaphnia acuminata Ekman, 1900: 69.

Syn.: Ceriodaphnia richardi Sars, 1901: 21.

Type Series. Type locality: "lac Toba," N Sumatra, Indonesia.

Type Material. David G. Frey (DGF) collection was housed in Smithsonian Institution's Museum Support Center in Suitland, Maryland, USA. According to the hand written catalogue, sample DGF 723 was from "Balige (Lac Toba, Sumatra)," coll. in 24.xi.1891 by M. E. Modigliani. However, according to the label, this sample is from Lake Titicaca and collected in 1969. So the initial sample with number 723 is no longer present in the collection, and there are no other samples from Lake Toba in Richard's collection" [35].

Specimens Identified as Ceriodaphnia dubia Richard, 1894

Nontype Material. Australia: Victoria, no other data, NHMUO F19258 (in ethanol). South Africa: Cape of Good Hope, no other data, NHMUO F9266 (slide collection); Cape of Good Hope, no other data, NHMUO F9267 (slide collection). Central Africa: Lake Victoria, no other data, NHMUO F9309 (slide collection). Indonesia: Lake Toba, Sumatra, 1891-02-24, Frey, D. G. USNM 1120420 (100 specimens in ethanol).

\section{Specimens Identified as Ceriodaphnia affinis Lilljeborg, 1901}

Nontype Material. Sweden: Blekinge, Sturberg no other data, NHMUO F9583 (slide collection); Blekinge, Sturberg no other data, NHMUO F18489a (in ethanol); Blekinge, Sturberg no other data, NHMUO F18489b (in ethanol). Germany: Umgebung von Berlin, Hartwig, NMCL 11913.

Australia: slide of a dissected parthenogenetic female from Parramatta Lake near Sydney, NSW $\left(33^{\circ} 47^{\prime} 26^{\prime \prime} \mathrm{S} /\right.$ $\left.151^{\circ} 00^{\prime} 28^{\prime \prime} \mathrm{E}\right)$, deposited in the South Australia Museum (SAM). Dr. John Chapman (Office of Environment and Heritage, NSW, Sydney) collected this species in 1986 from Parramatta Lake in Sydney and since then it has been cultured and maintained in a laboratory (Moreno Jully, OEH, NSW, personal communication, 23 June 2014). Sample specimens of the species were provided by Dr. Tsuyoshi Kobayashi $(\mathrm{OEH}$, NSW) on 26/10/2010. Genetic Reference number: COI + 16s = SYDCB001 - 05. Five ephippial females (undissected) stored in a vial containing $70 \%$ denatured alcohol deposited in the SAM, accession number SAM C7024.

Diagnosis. Parthenogenetic females: head small, 4.8 to 5.6 times of body length, moderately depressed with shallow 


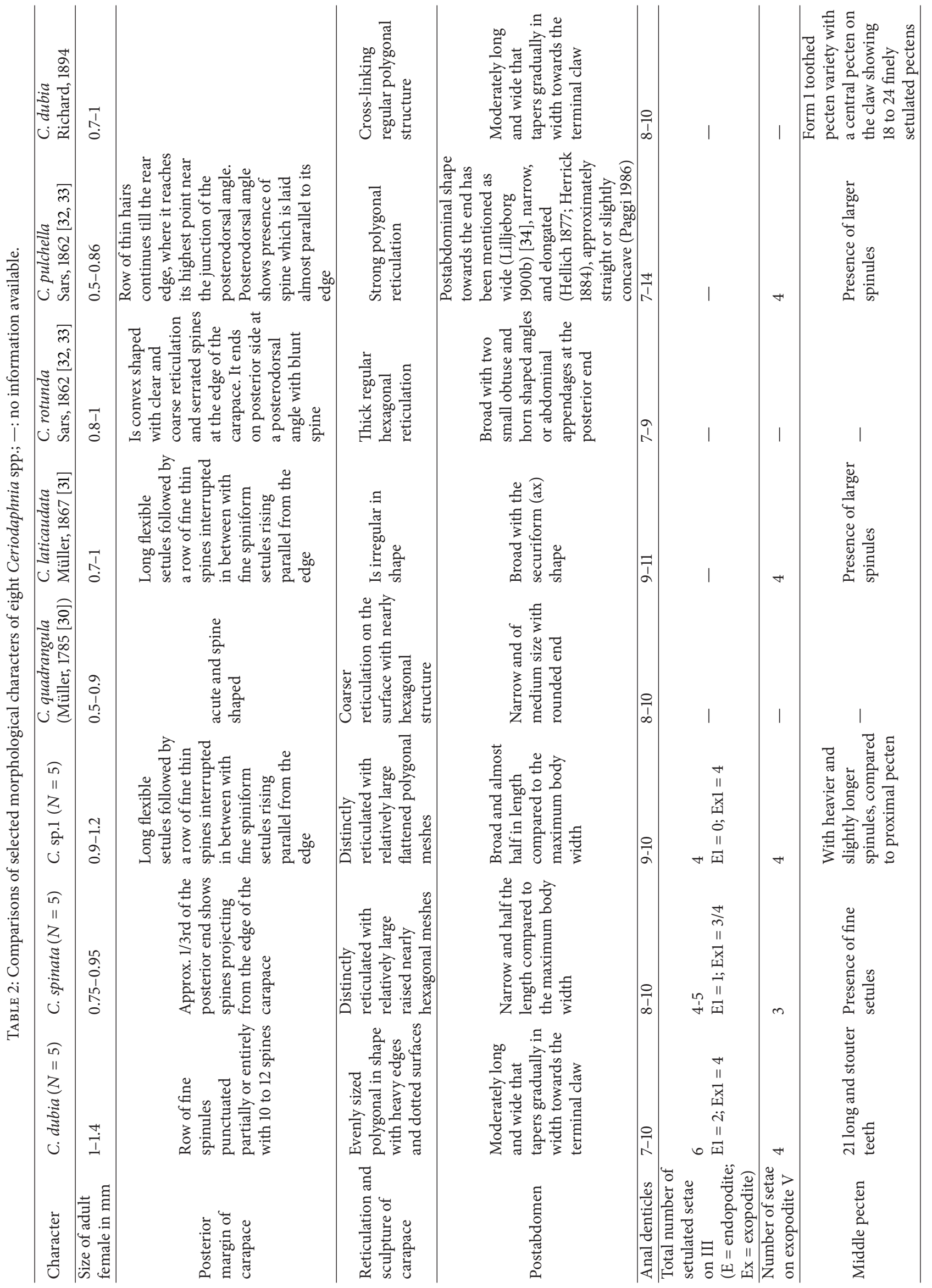


supraocular depression, elongated polygonal reticulations over frons, no fenestra on anterior surface of cervical notch. Eye moderately large in size, 2.1 to 2.6 times in head length, lenses prominent. Fornix smoothly rounded without lateral extensions and without a minute spine at broadest portion (Figure 1(a)). The rostral region with flat round pore (Figure 1(d)). Antennules short, anterior sensory hair arising from small peduncle, one-third the distance from apex, anterior sensory hair longer than either antennule body or aesthetascs. Ridge of cuticle encircles rostral pore. Coxal portion of antennae folded, with two sensory setae. Surface of basipod with nine irregular rows of fine spinules varying in length and thickness. Posterior ventral carapace margin with inner row of fine spinules punctuated partially or entirely with 12 spines and with one to three short, heavier, plumose spines dorsally at about $40 \%$ of distance below the posterior ventral margin. Surface of the carapace with polygonal reticulations (Figure 2(a)).

Trunk limb I with setulated setae on endites two to five (E2 to E5). Two ejector hooks situated on the anterior side of the limb. Trunk limb II with five endites E1 to E5 consisting of seven setulated setae and two soft setae; the gnathobase bears five setae and E2 bears one long and one short accessory spines. Trunk limb III consists of one exopodite and five endites. Trunk limb IV with eight setulated setae. Trunk limb $\mathrm{V}$ with a small sized exopodite bearing four setae of which two are long and two are small in size (Figure 2(d)).

Postabdomen slightly tapered and obliquely truncated distally. There are about eight anal denticles (Figure 3(a)). The postabdominal claw setules of proximal group short and slightly lighter in weight than those of the distal group. Middle pecten with 21 long and stouter teeth (Figure 3(d)).

\subsubsection{C. sp. 1}

Holotype. Slide of a parthenogenetic female, Yanga Lake, Sydney, NSW $\left(34^{\circ} 42^{\prime} 19.04^{\prime \prime} \mathrm{S} / 143^{\circ} 35^{\prime} 30.73^{\prime \prime} \mathrm{E}\right)$. Collected by Dr. T. Kobayashi (OEH, NSW) on 26-10-2010 (SAM C7551).

Material Examined. Five parthenogenetic females from Yanga Lake near Sydney, NSW ( $\left.34^{\circ} 42^{\prime} 19.04^{\prime \prime} \mathrm{S} / 143^{\circ} 35^{\prime} 30.73^{\prime \prime} \mathrm{E}\right)$, in a vial containing 70\% denatured alcohol deposited in SAM, accession number SAM C7551. Barcode Reference: COI + 16s = NSYAN001 - 02, NSSTE002, NSMER003 - 05.

Diagnosis. Parthenogenetic females: head small, 3.9 to 4.33 times of body length and moderately depressed with shallow supraocular depression and irregular polygonal reticulations over frons. Fornix with extended hooks (Figure 1(b)). Cervical notch is not deep. Eye large in size, 1.9 to 2.25 times in head length, lenses prominent. Rostral region shows bulging vertical pore (Figure 1(e)). Antennules are long, anterior sensory hair rises from small peduncle $1 / 3$ rd distance from apex, anterior sensory hair longer than either the antennule body or aesthetascs. Coxal portion of antennae is folded and supplied with three sensory setae. Surface of basipod with 10 irregular rows of fine spinules varying in length and thickness. Posterior margin of carapace shows a line of fine spinules which are punctuated with spines. Surface of the carapace with hexagonal reticulations (Figure 2(b)).
Trunk limb I with setulated setae on endites 2 to 5 (E2 to E5), and two setae on E5. Trunk limb II comprises five endites E1 to E5, with four brush setae on gnathobase and two short accessory spines on E2. Trunk limb III exopodite consists of four setulated setae on the distal end and 2 small setulated setae on the lateral end. There are five endites on trunk limb III of which endites 1 to 4 are highly reduced and E5 bears a number of gnathobasic filtering setae. Trunk limb IV has five setulated setae at the distal end. Posterior end has two setae. Trunk limb V has a small sized exopodite bearing four setae of which two are long and two is smaller in size (Figure 2(e)).

Postabdomen is almost half in length compared to the maximum body width. There are eight recurved anal denticles (Figure 3(b)). The distal end of postabdominal claw is slightly concave and base is straight, with setules of proximal group being short and slightly lighter in weight than those of the distal group. Middle pecten with 31 long and thinner teeth (Figure 3(e)).

\subsubsection{Ceriodaphnia spinata Henry, 1919 (pI. XL, Figures 1 and 2). Ceriodaphnia spinata Henry, 1919: 466.}

Type Material. Holotype AMP 4327 (1 ovigerous female).

Type Series. Type locality: “Corowa”, Australia.

Nontype Material. Australia: Victoria, Thornton, 1998-10-09, USNM 1121570 (5ㅇ in isopropyl alcohol); 1121571 (6o, in isopropyl alcohol).

Material Examined. One female, Goulburn Billabong, Alexandria, Victoria, Australia, 06.08.1974 (AMP 27728); five ephippial females each from South Para Reservoir, Myponga Reservoir, Mannum and Snuggery Adelaide, SA; one parthenogenetic female from Mannum SAMAN001 $\left(36^{\circ} 16^{\prime} 29.99^{\prime \prime} \mathrm{S} / 139^{\circ} 54^{\prime} 40.41^{\prime \prime} \mathrm{E}\right)$, SA, sample collected by the author on 15/02/2009, deposited in SAM. Genetic Reference: COI + 16s = SAMAN001 - 02, SASNU001. Five ephippial females from Mandina (undissected) stored in a vial containing 70\% denatured alcohol deposited in SAM, accession number: SAMC7572.

Diagnosis. The holotype (P: 4327) is a mounted slide of ovigerous female. The second slide-mounted specimen (P: 27728) of the same length, from Goulburn billabong, Alexandria, Victoria, Australia, is poorly preserved. Smirnov and Timms (1983) reported the total length of females in the range 0.8 to $1.2 \mathrm{~mm}$.

Parthenogenetic Females. Head small, 5 to 5.5 times of body length, moderately depressed with absence of supraocular depression and presence of irregular polygonal and hexagonal reticulations, which are punctuated and stippled. Eye moderately large, 1.8 to 2.5 times in head length, lenses prominent. Edges or nodes of these reticulations are an acute V-shaped structure. Cervical notch not deep. Fornix with two small smooth denticles (Figure 1(c)). The rostral region shows flat round pore (Figure 1(f)). Eye moderately large size and lenses are prominent. Antennules are long, anterior sensory hair rises from small peduncle which is approximately half 


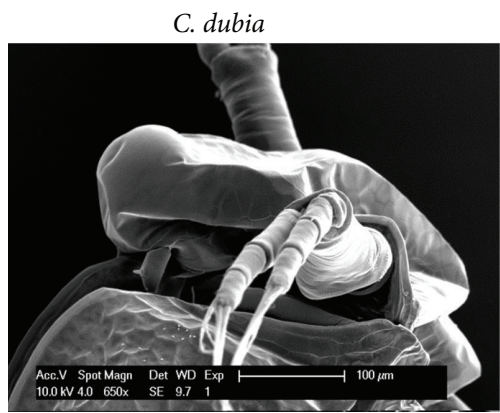

(a)

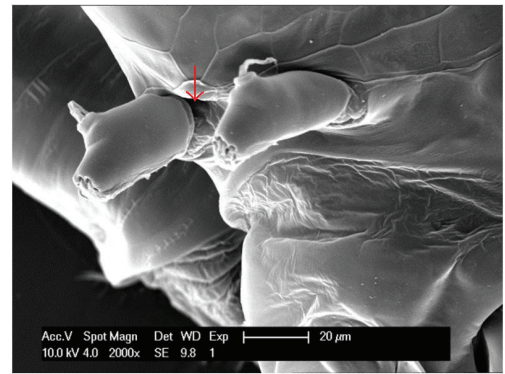

(d)

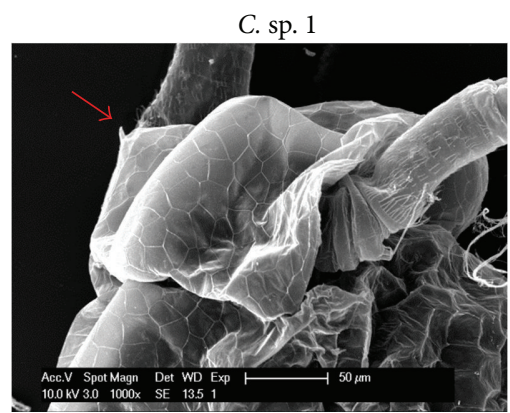

(b)

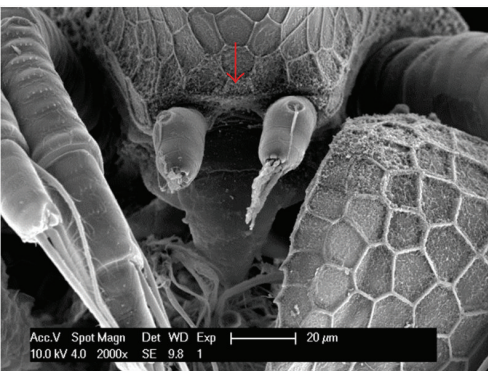

(e)

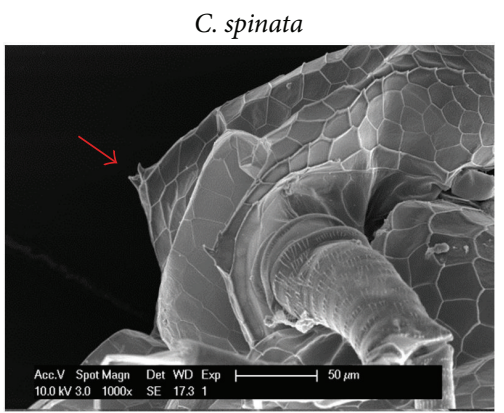

(c)

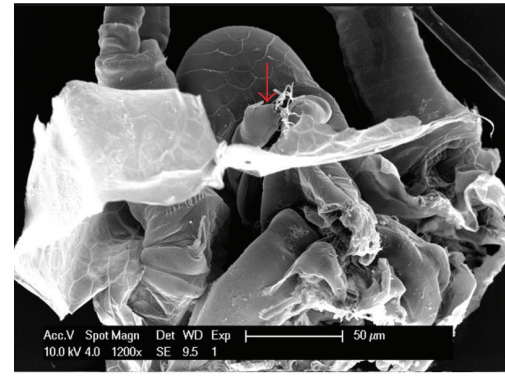

(f)

FIGURE 1: ((a)-(c)) SEMs of fornix. (a) Absence of denticles; (b) smooth extended hooks; (c) smooth small denticles. ((d)-(f)) SEMs of the rostral pore. (d) Flat; (e) bulging; (f) flat.

C. dubia

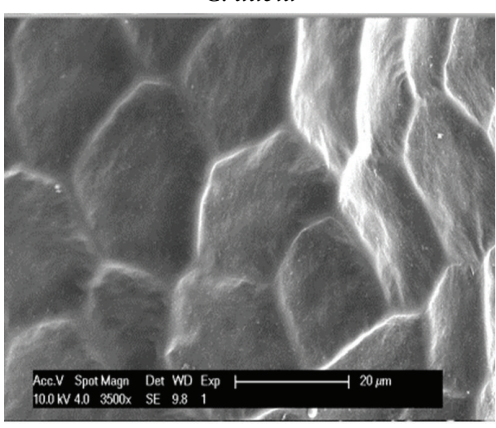

(a)

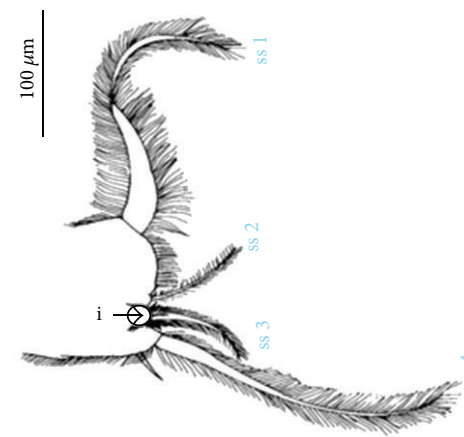

(d)

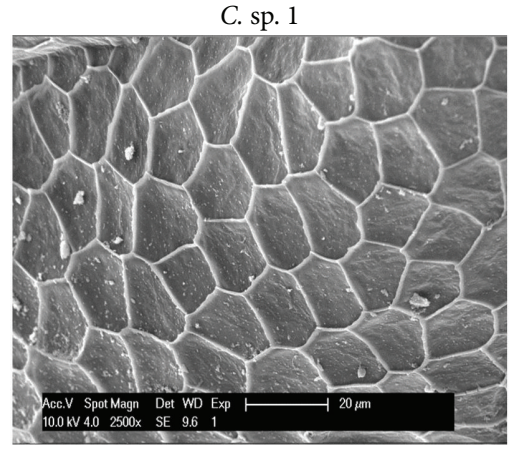

(b)

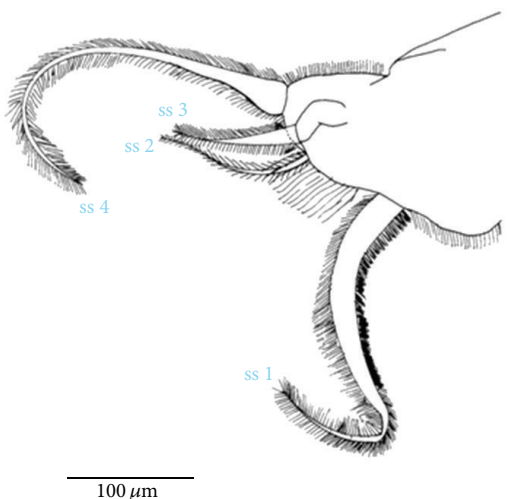

(e)

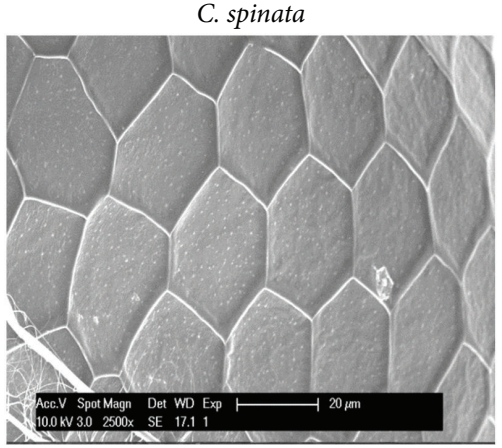

(c)

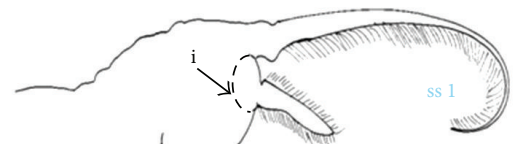

Figure 2: ((a)-(c)) SEMs of reticulation on the carapace. (a) Polygonal reticulation; ((b) and (c)) hexagonal reticulation. ((d)-(f)) Line drawing of Trunk Appendage V for the three species. 


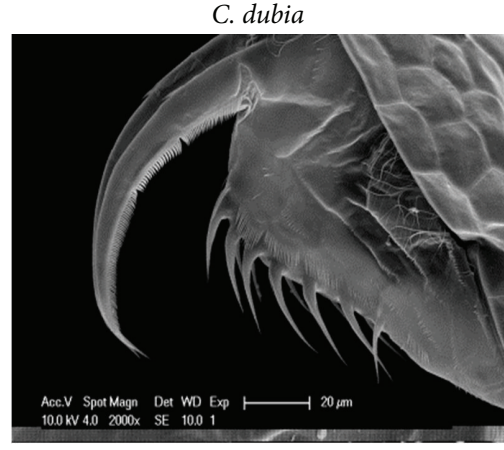

(a)

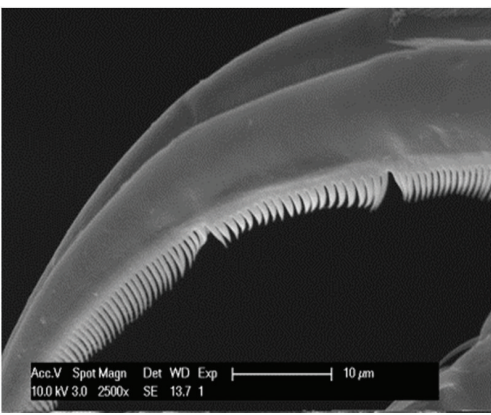

(d)

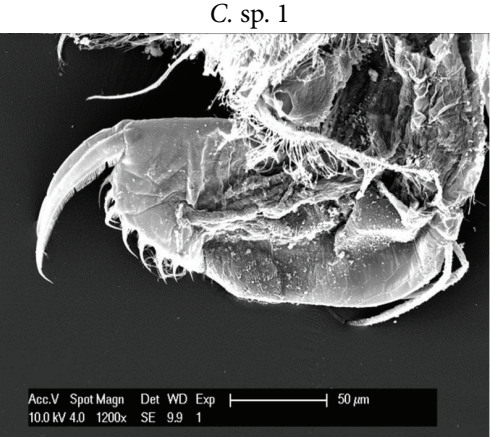

(b)

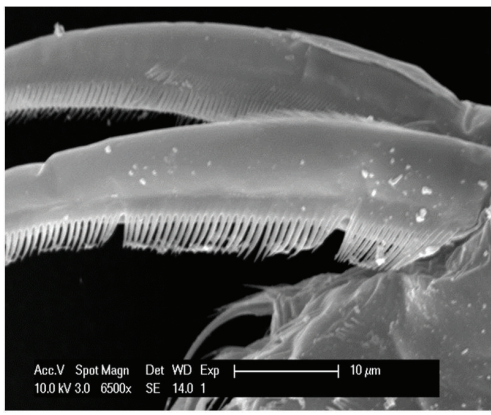

(e)

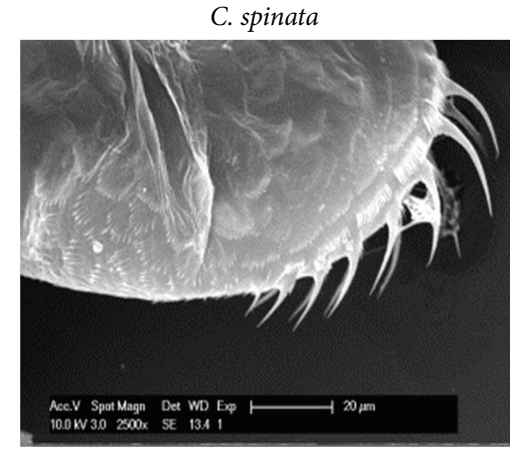

(c)

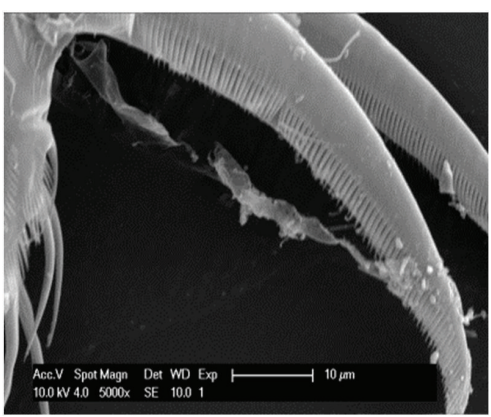

(f)

FIGURE 3: SEMs of postabdomen and denticles of the three species.

the distance from apex, anterior sensory hair longer than either the antennule body or aesthetascs. Coxal portion of antennae is folded and supplied with two sensory setae; lateral basal section of the basipod shows presence of ten plumose setae. Surface of basipod shows ten irregular rows of fine spinules varying in length and thickness. Posterior margin of the carapace shows no punctuating spine, unlike $C$. sp. 1 Posterodorsal angle is pointed and spiny. Surface of the carapace with hexagonal reticulations (Figure 2(c)).

Trunk limb I with setulated seta on endites 2 to 5 (E2 to E5); E5 shows the presence of three setae. Trunk limb II comprises of five endites E1 to E5: the gnathobase bears five brush setae and E2 bears two long accessory spines. Trunk limb III exopodite consists of three setulated setae on distal end and one small setulated seta on the lateral end. Trunk limb IV has four setulated setae in the distal end and the posterior end has a single seta. Trunk limb V has a small sized exopodite bearing three setae of which the distal and proximal one are the longest compared to middle setae (Figure 2(f)).

Postabdomen is almost half the length compared to maximum body width. There are nine recurved anal denticles (Figure 3(c)). The distal end of postabdominal claw is slightly concave and base is curved, with setules of proximal group shorter and thinner than those of the distal group (Figure 3(f)).

3.2. Phylogenetic Relationships Derived from cmtDNA. Basic statistics and selected substitution models for mtDNA sequences are shown in Table 3 . The cmtDNA set yielded a total of 14 unique sequences, consisting of 1185 aligned nucleotides, of which 220 sites were variable and 216 sites were parsimony informative. No internal stop codons and indels were detected. Trees based on individual gene fragments (not shown) and on cmtDNA (Figure 4) as well as nuclear marker 28s (Figure 5) yielded similar topologies in which:

(1) Clade 1 and Clade 2 comprising C. sp. 1 and C. spinata were supported by $100 \%$ bootstrap support and include populations from NSW and SA. Intraspecific pairwise differences for cmtDNA ranged between 0 and $1 \%$, while minimal observed interspecific distance was $10 \%($ ML corrected $=13 \%)($ Table 4$)$;

(2) Clade 3 comprising C. dubia was represented by laboratory cultured species from Parramatta, NSW, with bootstrap value of $100 \%$ and intraspecific divergence of $0 \%$ for cmtDNA (Table 4 ).

3.3. Comparison between Australian and North American Populations of Ceriodaphnia. Analysis of COI sequences between Australian C. sp. 1 and C. spinata and North American species of Ceriodaphnia (Figure 6) showed raw pdistance analysis between 2 and 21\%, whereas corrected MLdistance analysis is 18 to $103 \%$ (Table 5). The exceptions to this are SYDCB001 and SYDCB003 specimens from Parramatta, NSW, which show genetic similarity with ZPLMX 452 and ZPLMX453 (Ceriodaphnia cf. laticaudata, Mexico); ZPLMX095 and ZPLMX859 (Ceriodaphnia cf. acanthina, 


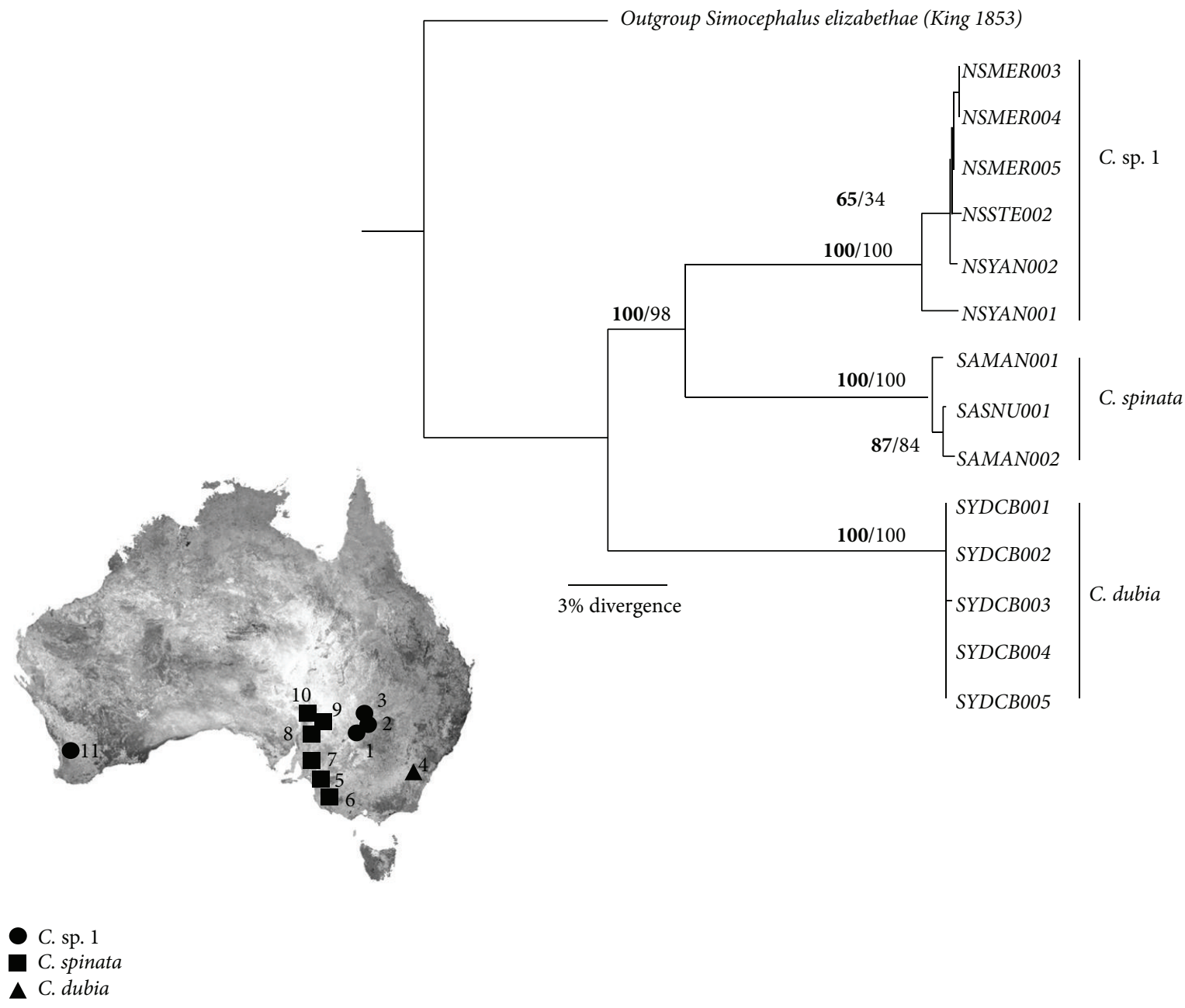

FIgURE 4: Phylogenetic trees inferred from concatenated mtDNA gene sequences for Ceriodaphnia within Australia. Numbers above branches are maximum likelihood (100 replicates) and numbers in bold are from Bayesian analysis. For location details refer to Table 1.

TABLE 3: Sequence information for the different gene fragments without the outgroup. Fragment length in base pair, number of variable sites $(V)$, and number of gap positions or missing data $(G / M)$.

\begin{tabular}{lcccc}
\hline Gene fragments & Length & $V$ & $G / M$ & Model test \\
\hline mtDNA & & & & \\
$\quad$ 16s & 540 & 75 & - & K81uf + I \\
COI & 645 & 148 & - & K81uf + G \\
$\quad$ cmtDNA & 1185 & 220 & - & TVM + G \\
Nuclear & & & & \\
$\quad 28 s$ & 575 & 479 & - & GTR + I + G \\
\hline
\end{tabular}

Mexico) with $1-4 \%$ (raw p-distance) and ML distance of 1 to $6 \%$.

\section{Discussion}

Molecular analysis of the published COI sequences available from GenBank including the sequences generated from this
TABle 4: Minimum and maximum $\mathrm{cmt}$ mtDNA (upper line in each cell) and 28s (bold bottom line in each cell) raw pairwise divergence within and between Ceriodaphnia species, with ML corrected divergence value inside the closed bracket (). The figures are in percentage (\%) and 0 represents the sequence divergence value being $<0.005 \%$.

\begin{tabular}{|c|c|c|c|}
\hline Species & C. sp. 1 & C. spinata & C. dubia \\
\hline C. sp. 1 & $\begin{array}{l}0-1(0-1) \\
0-1(0-1)\end{array}$ & & \\
\hline C. spinata & $\begin{array}{c}10(13-15) \\
\mathbf{8}(\mathbf{9}-10)\end{array}$ & $\begin{array}{c}0-1(0-1) \\
\mathbf{0}(\mathbf{0})\end{array}$ & \\
\hline C. dubia & $\begin{array}{c}14(24-25) \\
\mathbf{1 2 - 1 4}(\mathbf{1 7 - 1 9 )}\end{array}$ & $\begin{array}{c}15(26-27) \\
\mathbf{9 - 1 0}(\mathbf{1 2 - 1 4})\end{array}$ & $\begin{array}{c}0(0) \\
0-2(0-2)\end{array}$ \\
\hline
\end{tabular}

study (Figures 4 and 5) indicates the presence of three distinct Ceriodaphnia species. This is also well supported by morphology which showed consistent differences of ten key characters among and between C. dubia, C. sp. 1 , and $C$. spinata. 


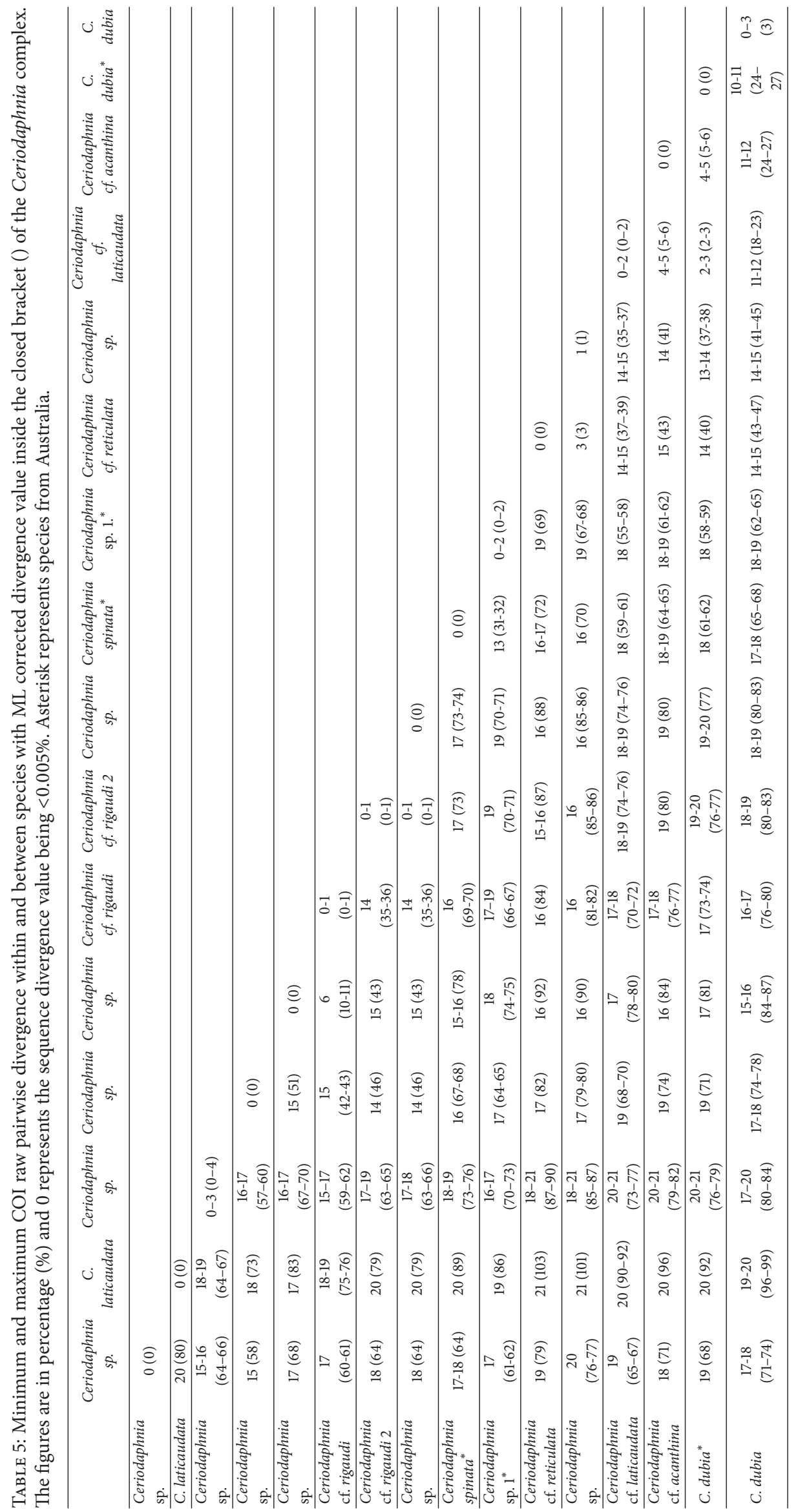




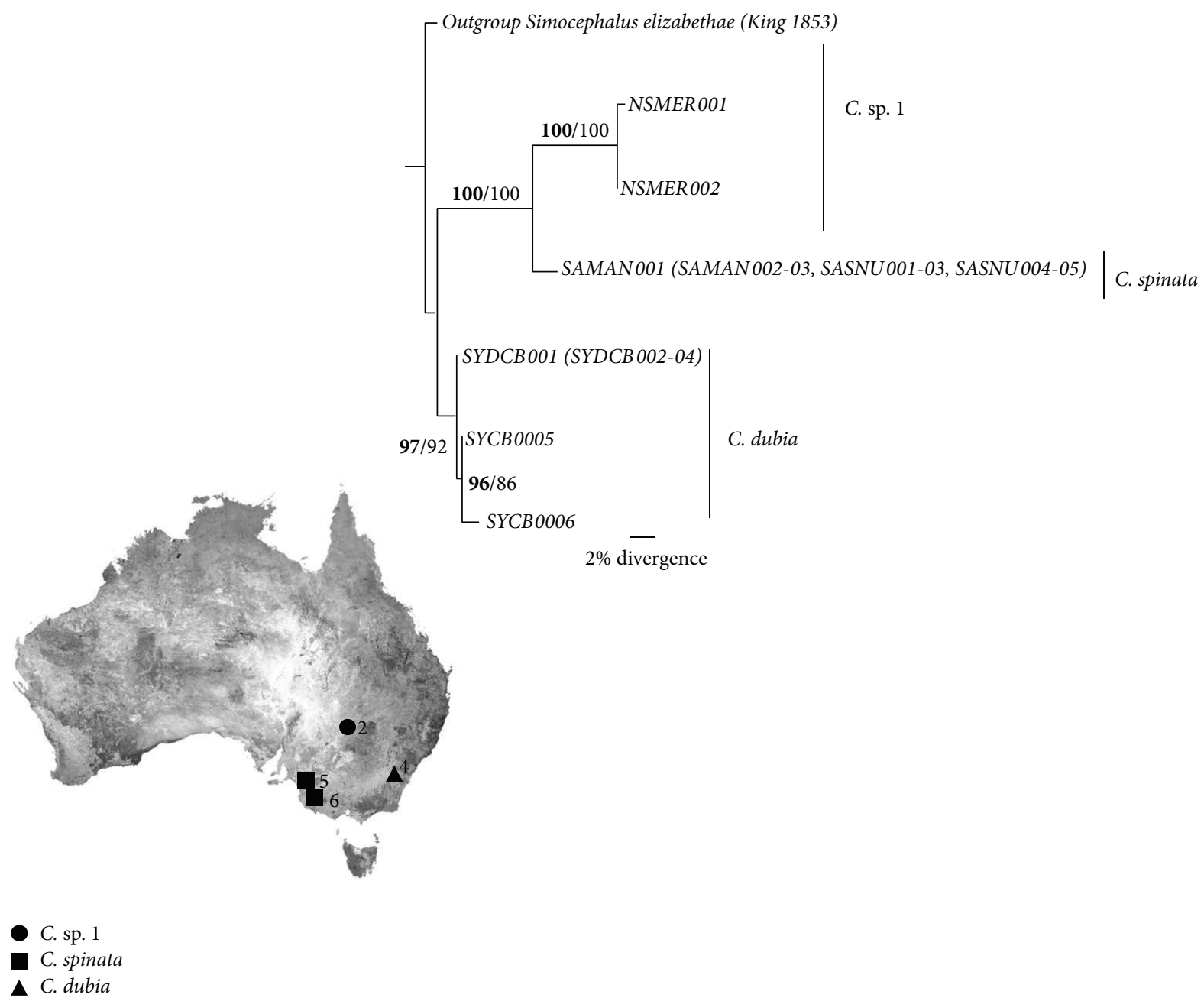

FIGURE 5: Tree indicating the phylogenetic relationship inferred from 28s gene sequences for Ceriodaphnia within Australia. Numbers above branches are maximum likelihood (100 replicates) and numbers in bold are from Bayesian analysis. For location details refer to Table 1.

The specimens of C. dubia from Sydney, NSW (SYDCB), and specimens identified as C. dubia Richard, 1894, are morphologically the same. The C. dubia specimen from Sydney, NSW (SYDCB), appears to be morphologically the same as C. dubia Richard, 1894 in a "strict sense" (Berner, personal communication), hence C. dubia s.s. The variation in the number of setules on pecten has been highlighted by Berner (1986) [36] in US EPA report, were two form of toothed pecten variation of C. dubia was observed only under controlled environmental and nutritional conditions. However, the C. dubia description from New Zealand by Greenwood et al.(1991) [37] is similar to Berner (1986) [36] description of Form 1 toothed pecten variety with a central pecten on the claw showing 18 to 24 heavy finely setulated pecten, which are slightly longer than those of the adjacent setules, similar to C. dubia s.s studied here.

The lack of sufficient taxonomic detail for Australian Ceriodaphnia has resulted in incorrect identifications, leading to a great deal of confusion, with synomization or clustering several distinct species like C. planiformis and C. spinata with C. quadrangula Lilljeborg (1900) [34], a holarctic species. C. planiformis and C. spinata are endemic Australian species and therefore are not synonymous with C. quadrangula. The variations in size and shape of the postabdomen, number of setae on endopodite of limbs I, II, and V, presence or absence of punctuating spines along the posterior margin of the carapace, and variation in thickness of spinules of the middle pecten are stable characters that all point toward $C$. planifrons and C. spinata being distinctly separate species. These characters are also comprehensively documented by line drawings and SEM images by Berner [4].

Despite close morphological similarities of C. sp. 1 with $C$. planifrons reported by Berner [4], the loss of the holotype, and lack of well-preserved specimens of C. planifrons, nothing definitive can be said about this species.

There are a total of 11 unmounted specimens, approximately 30 years old, of $C$. spinata lodged in the Smithsonian Institution under accession codes 1121570 and 1121571 in Isopropyl alcohol. Isopropyl alcohol or isopropanol (IPA) has been a preferred choice for museums to store specimens for long term storage. Also, failure in extracting and amplifying DNA from $>5$ years preserved samples, in this study, available unmounted original material of C. spinata was not used for the genetic study. However, comparative light microscopical 


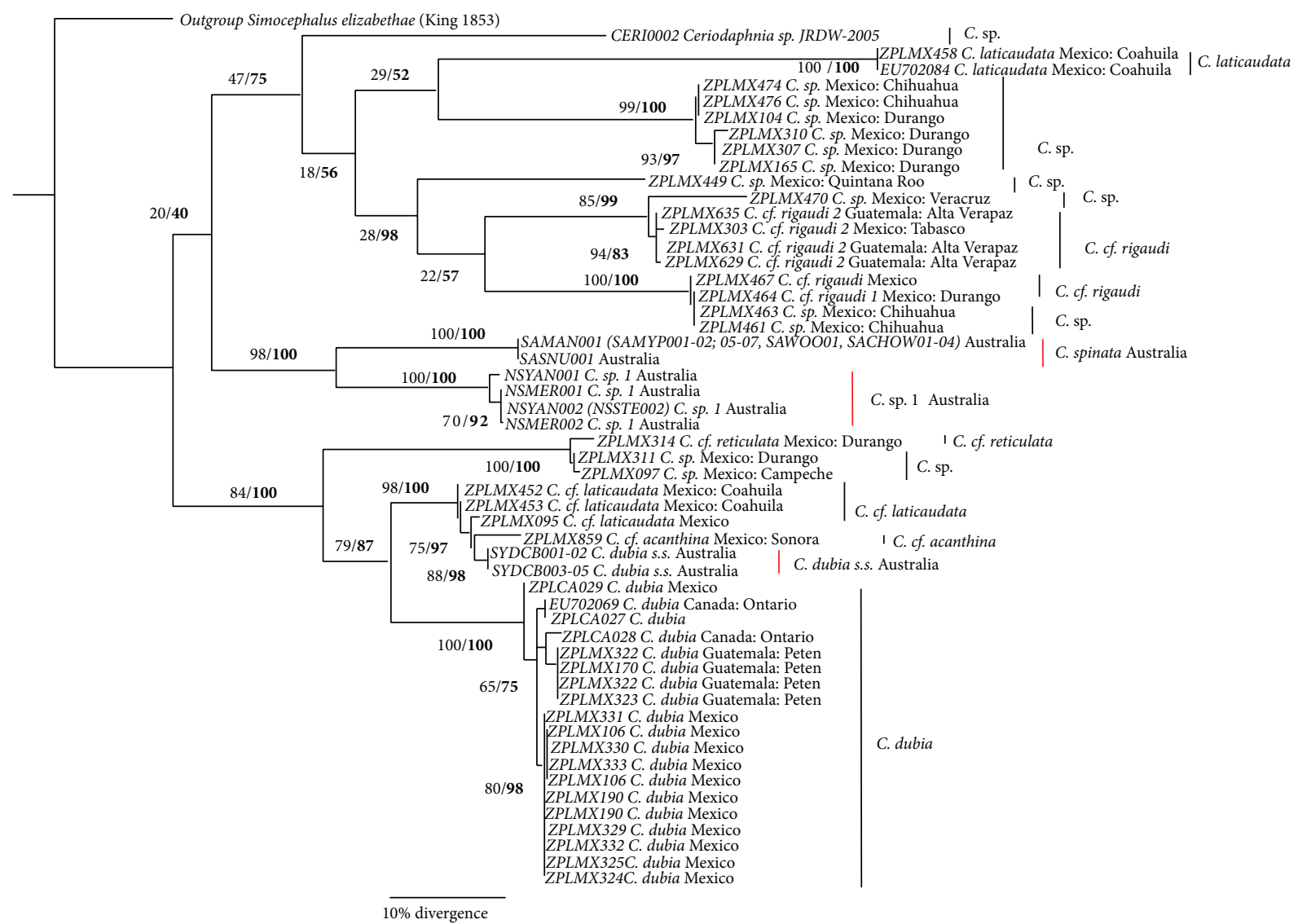

FIgure 6: Maximum likelihood analysis of COI gene for Ceriodaphnia complex. Numbers above branches are maximum likelihood (100 replicates) and numbers in bold are from Bayesian analysis. Red bar represents species from Australia.

analysis of the type slide specimen and comparison with documented SEM and line drawings of Berner [4] helped narrow the third species to C. spinata.

4.1. Phylogenetic Analysis. Phylogenetic relationships among species of Ceriodaphnia from Australia showed congruence between cmtDNA and nuclear gene tree topology with strong bootstrap support (Figures 4 and 5). The average bootstrap support values were moderate to high, suggesting that topologies estimated are reliable. Nevertheless, closely related species living in the same region formed a strongly supported monophyletic group C. sp. 1 and C. spinata. The low level of genetic divergence seen for C. dubia is probably due to the specimens being from a panmictic population from Parramatta River and laboratory cultured and maintained since 1986 (Julli, pers. comm.).

Phylogenetic analysis of $\mathrm{mt}$ COI sequences for Ceriodaphnia from different sites, many of which are from Mexico Elías-Gutiérrez [38], provided the first direct molecular evidence for genetic divergence between geographically isolated populations of Ceriodaphnia. Close genetic similarities between $C$. cf. laticaudata (raw p-distance of 2 to 3\%, ML distance of 2 to 3\%) and C. cf. acanthina (raw p-distance of 4 to $5 \%, \mathrm{ML}$ distance of 5 to $6 \%$ ) from Mexico to C. dubia and conversely large genetic differences with C. dubia (raw pdistance of 10 to 11 , ML distance of 24 to 27\%) from Guatemala and Mexico indicate that the Australian population of $C$. dubia is genetically distinct and morphologically discrete.

In this work an integrated approach was used for achieving the goal of species identification and discrimination of Ceriodaphnia from Australia. The correlation between morphological and molecular identifications in this study indicates that both COI and 16s rRNA are appropriate molecular markers for species discrimination and identification of genus Ceriodaphnia. From this perspective the present study not only illustrates the usefulness of a combined morphogenetic approach for the relatively understudied genus Ceriodaphnia, but also provides the first DNA barcode reference for the three Australian Ceriodaphnia species studied.

\section{Conflict of Interests}

The author declares that there is no conflict of interests regarding the publication of this paper.

\section{Acknowledgments}

The author would like to thank the Sir Mark Mitchell Research Foundation, ANZ Holsworth Grant, and ABRS Travel Bursary for financial support. The author appreciates very much the helpful suggestions on the paper from Dr. John Jennings and Dr. Tsuyoshi Kobayashi. The author also 
extends sincere thanks to SA Water, Microbiology Department, for granting the permission and providing the necessary facilities to carry out the genetic work. The author greatly appreciates the helpful suggestions on the English from Ms. Samantha-Ann Schneider. The author would like to thank the reviewers for their comments that helped improve the paper. Thanks also go to all the staff at Adelaide Microscopy, for there assistance with the SEM.

\section{References}

[1] A. Kotov, L. Forró, N. M. Korovchinsky, and A. Petrusek, World Checklist of Freshwater Cladocera Species, 2013.

[2] N. N. Smirnov and B. V. Timms, Revision of the Australian Cladocera (Crustacea), The Australian Museum, Sydney, Australia, 1983.

[3] R. J. Shiel, "A guide to identification of Rotifers, Cladocerans and Copepods from Australian Inland Waters," CRCFE and MDBC Identification Guide 3, Cooperative Research Centre for Freshwater Ecology, Murray-Darling Freshwater Research Centre, Albury, Australia, 1995.

[4] D. B. Berner, "Rediscriptions of Ceriodaphnia planifrons and C. hakea, Smith 1909 and of C. spinata Henry, 1919 (Crustacea, Cladocera, Anomopoda, Daphniidae)," in Proceedings of the Joint Congress of ASL \& NZLS, 2003.

[5] A. J. Barnett, K. Finlay, and B. E. Beisner, "Functional diversity of crustacean zooplankton communities: towards a trait-based classification," Freshwater Biology, vol. 52, no. 5, pp. 796-813, 2007.

[6] J. W. Sites Jr. and J. C. Marshall, "Operational criteria for delimiting species," Annual Review of Ecology, Evolution, and Systematics, vol. 35, pp. 199-227, 2004.

[7] P. D. N. Hebert, "A revision of the taxonomy of the genus Daphnia (Crustacea: Daphnidae) in south-eastern Australia," Australian Journal of Zoology, vol. 25, pp. 371-398, 1977.

[8] J. A. H. Benzie, "Phylogenetic relationships within the genus Daphnia ( Cladocera: Daphniidae) in Australia, determined by electrophoretically detectable protein variation.," Australian Journal of Marine \& Freshwater Research, vol. 37, no. 2, pp. 251260, 1986

[9] J. K. Colbourne, C. C. Wilson, and P. D. N. Hebert, "The systematics of Australian Daphnia and Daphniopsis (Crustacea: Cladocera): A shared phylogenetic history transformed by habitat-specific rates of evolution," Biological Journal of the Linnean Society, vol. 89, no. 3, pp. 469-488, 2006.

[10] P. D. N. Hebert and T. L. Finston, "Genetic differentiation in Daphnia obtusa: a continental perspective," Freshwater Biology, vol. 35, no. 2, pp. 311-321, 1996.

[11] K. Schwenk, Evolutionary Genetics of Daphnia Species Complex: Hybridism in Syntopy, Publication 2231, Netherlands Institute of Ecology, Centre for Limnology, Nieuwersluis, The Netherlands, 1996.

[12] K. Schwenk, A. Sand, M. Boersma et al., "Genetic markers, genealogies and biogeographic patterns in the cladocera," Aquatic Ecology, vol. 32, no. 1, pp. 37-51, 1998.

[13] D. J. Taylor and P. D. N. Hebert, "Daphnia galeata mendotae as a cryptic species complex with interspecific hybrids," Limnology and Oceanography, vol. 37, no. 3, pp. 658-665, 1992.
[14] D. J. Taylor and P. D. N. Hebert, "Cryptic intercontinental hybridization in Daphnia (Crustacea): the ghost of introductions past," Proceedings of the Royal Society B: Biological Sciences, vol. 254, no. 1340, pp. 163-168, 1993.

[15] L. J. Weider and A. Hobaek, "Molecular biogeography of clonal lineages in a high-arctic apomictic Daphnia complex," Molecular Ecology, vol. 3, no. 5, pp. 497-506, 1994.

[16] J. K. Colbourne, M. E. Pfrender, D. Gilbert et al., "The ecoresponsive genome of Daphnia pulex," Science, vol. 331, no. 6017, pp. 555-561, 2011.

[17] V. Kořinek, "Cladocera," in A Guide to Tropical Freshwater Zooplankton, C. H. Fernando, Ed., pp. 69-122, Backhuys Publishers, Leiden, The Netherlands, 2002.

[18] D. B. Berner, "Significance of head and carapace pores in Ceriodaphnia (Crustacea, Cladocera)," Hydrobiologia, vol. 145, no. 1, pp. 75-84, 1987.

[19] D. B. Berner and G. Rakhmatullaeva, "A new species of Ceriodaphnia from Uzbekistan and Kazakhstan," Hydrobiologia, vol. 442, pp. 29-39, 2001.

[20] O. Folmer, M. Black, W. Hoeh, R. Lutz, and R. Vrijenhoek, "DNA primers for amplification of mitochondrial cytochrome c oxidase subunit I from diverse metazoan invertebrates.", Molecular marine biology and biotechnology, vol. 3, no. 5, pp. 294-299, 1994.

[21] C. Simon, F. Frati, A. Beckenbach, B. Crespi, H. Liu, and P. Flook, "Evolution, weighting, and phylogenetic utility of mitochondrial gene sequences and a compilation of conserved polymerase chain reaction primers," Annals of the Entomological Society of America, vol. 87, pp. 651-701, 1994.

[22] D. Fontaneto, E. A. Herniou, C. Boschetti et al., "Independently evolving species in asexual bdelloid rotifers," PLoS Biology, vol. 5, no. 4, article e87, 2007.

[23] T. A. Hall, "BioEdit: a user-friendly biological sequence alignment editor and analysis program for Windows 95/98/NT," Nucleic Acids Symposium Series, vol. 41, pp. 95-98, 1999.

[24] K. Tamura, D. Peterson, N. Peterson, G. Stecher, M. Nei, and S. Kumar, "MEGA5: molecular evolutionary genetics analysis using maximum likelihood, evolutionary distance, and maximum parsimony methods," Molecular Biology and Evolution, vol. 28, no. 10, pp. 2731-2739, 2011.

[25] T. M. Keane, T. J. Naughton, and J. O. McInerney, ModelGenerator: Amino Acid and Nucleotide Substitution Model Selection, National University of Ireland, Maynooth, Maynooth, Ireland, 2004.

[26] S. Guindon and O. Gascuel, "A simple, fast, and accurate algorithm to estimate large phylogenies by maximum likelihood," Systematic Biology, vol. 52, no. 5, pp. 696-704, 2003.

[27] J. P. Huelsenbeck, F. Ronquist, R. Nielsen, and J. P. Bollback, "Bayesian inference of phylogeny and its impact on evolutionary biology," Science, vol. 294, no. 5550, pp. 2310-2314, 2001.

[28] A. Rambaut and A. Drummond, Tracer Version 1.5, Tracer, 2007, http://beast.bio.ed.ac.uk/.

[29] M. Elías-Gutiérrez, M. Jerónimo, V. N. Ivanova, M. Valdezmoreno, and P. D. N. Hebert, "DNA barcodes for Cladocera and Copepoda from Mexico and Guatemala, highlights and new discoveries," Zootaxa, vol. 42, no. 1839, pp. 1-42, 2008.

[30] O. F. Müller, "Entomostraca seu Insecta Testacea, quae in aquis Daniae et Norvegiae reperit, descripsit et iconibus illustravit," Lipsiae et Havniae, pp. 1-135, 1785.

[31] P. E. Muller, "Danmarks Cladocera," Naturqstorisk Tidsskrift, vol. 3, pp. 53-240, 1867. 
[32] G. O. Sars, "Meddeelte en af talrige Afbildninger ledsaget ovesigt af de ham i Omegmen af Christiania iagtagne Crustacea Cladocera," Forhandlinger i Videnskabs-Selskabet $i$ Christiania, vol. 1861, pp. 144-167, 1862.

[33] G. O. Sars, "Fortsatte sit Foredrag over de af ham i Omegmen af Christiania iagttanne Crustacea," Forhandlinger $i$ VidenskabsSelskabet i Christiania, vol. 1861, pp. 250-302, 1862.

[34] W. Lilljeborg, Cladocera Sueciae; oder Beiträge zur kenntniss der in Schweden lebenden Krebsthiere von der Ordnung der Branchiopoden und der Unterordnung der Cladoceren, Druck der akademischen buchdruckerei E. Berling, Upsala, Germany, 1900.

[35] A. A. Kotov and D. F. Ferrari, "The taxonomic research of Jules Richard on Cladocera (Crustacea: Branchiopoda) and his collection at the National Museum of Natural History, U.S.A," Zootaxa, vol. 2551, pp. 37-64, 2010.

[36] D. B. Berner, Taxonomy of Ceriodaphnia (Crustacea: Cladocera) in U.S. Environmental Protection Agency Cultures, Environmental Monitoring and Support Laboratory, Cincinnati, Ohio, USA, 1986.

[37] T. L. Greenwood, J. D. Green, and M. A. Chapman, "New Zealand Ceriodaphnia species: identification of Ceriodaphnia dubia Richard, 1894 and Ceriodaphnia cf. pulchella Sars," New Zealand Journal of Marine and Freshwater Research, vol. 25, pp. 283-288, 1991.

[38] M. Elías-Gutiérrez, F. M. Jerónimo, N. V. Ivanova, M. ValdezMoreno, and P. D. N. Hebert, "DNA barcodes for Cladocera and Copepoda from Mexico and Guatemala, highlights and new discoveries," Zootaxa, no. 1839, pp. 1-42, 2008. 

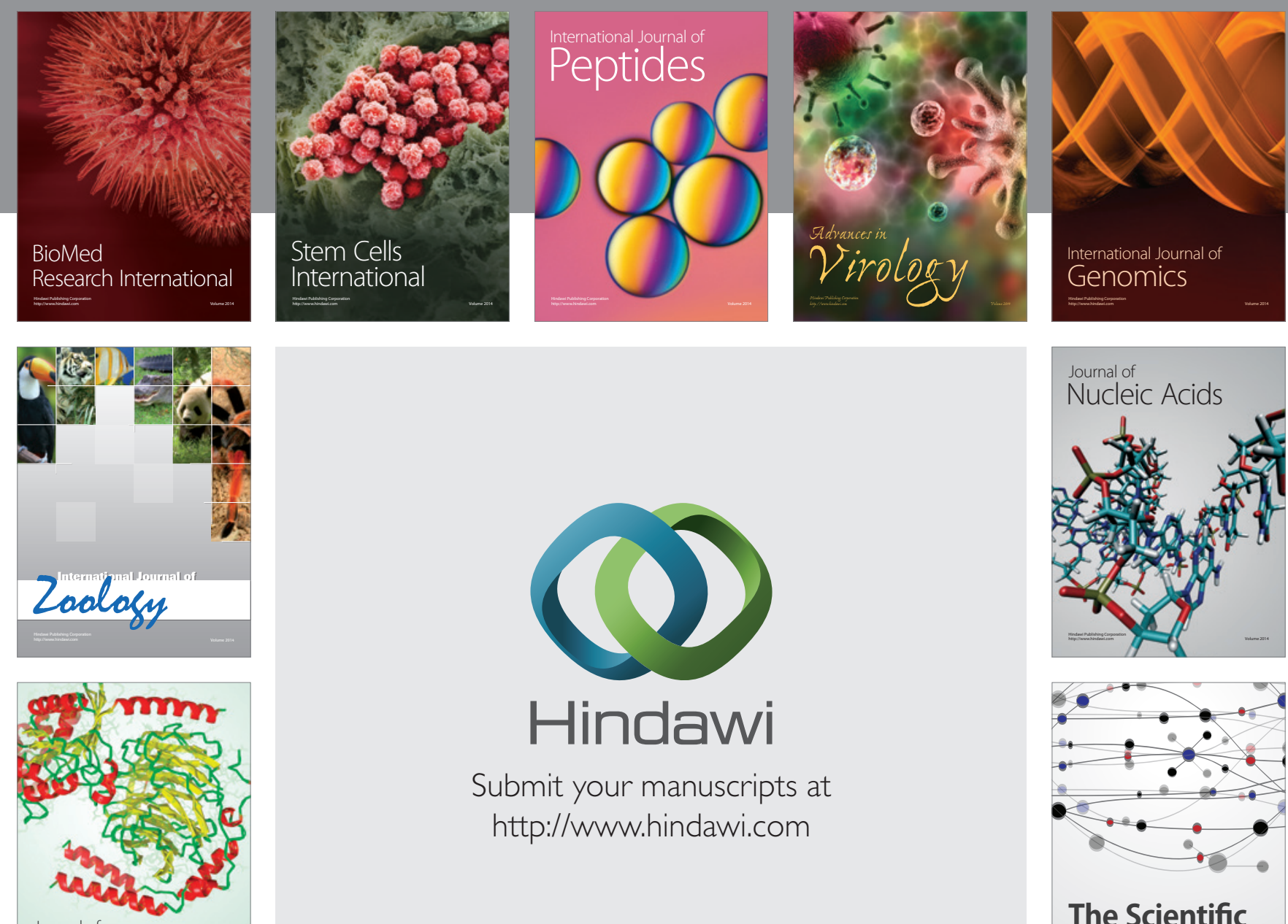

Submit your manuscripts at

http://www.hindawi.com

Journal of
Signal Transduction
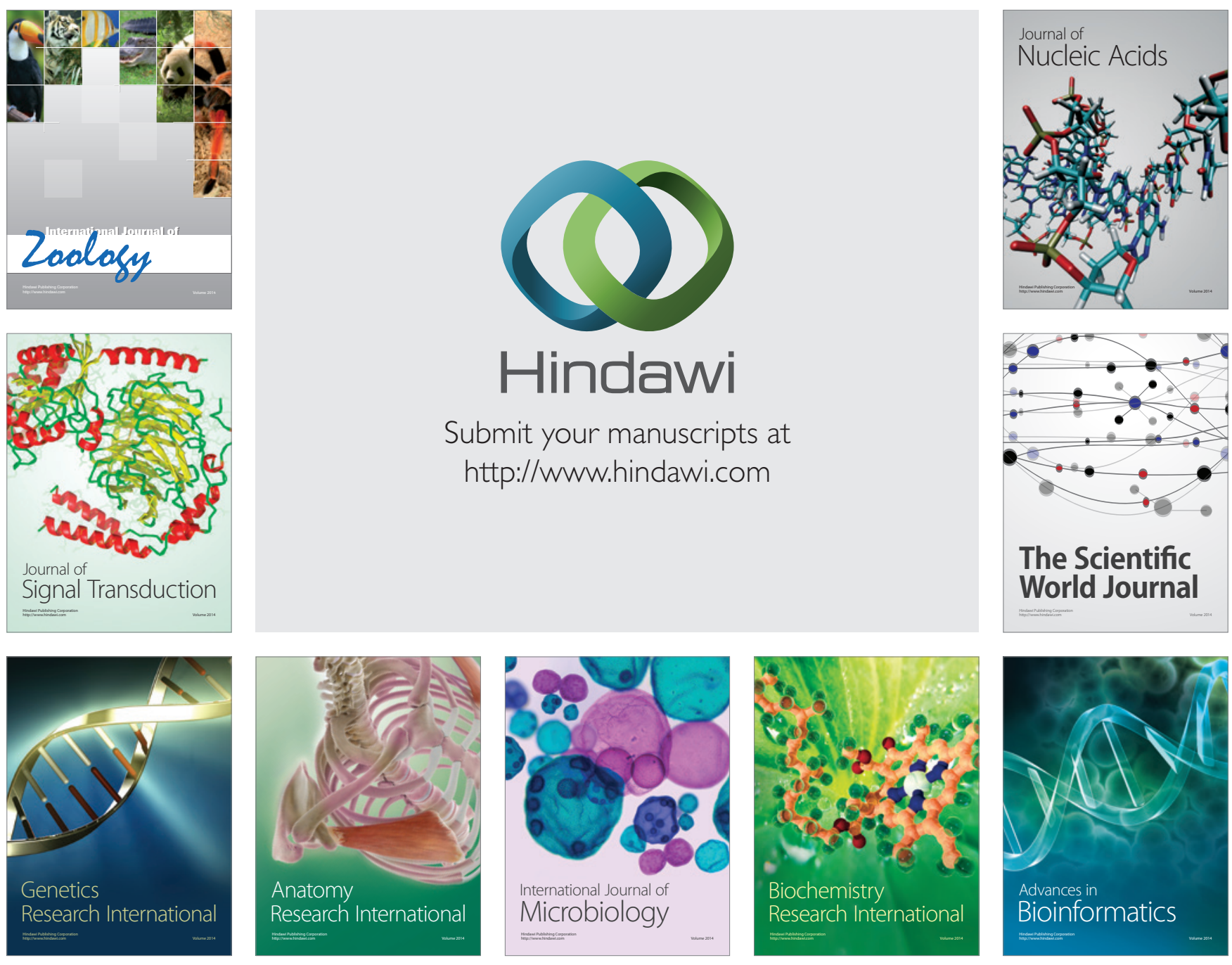

The Scientific World Journal
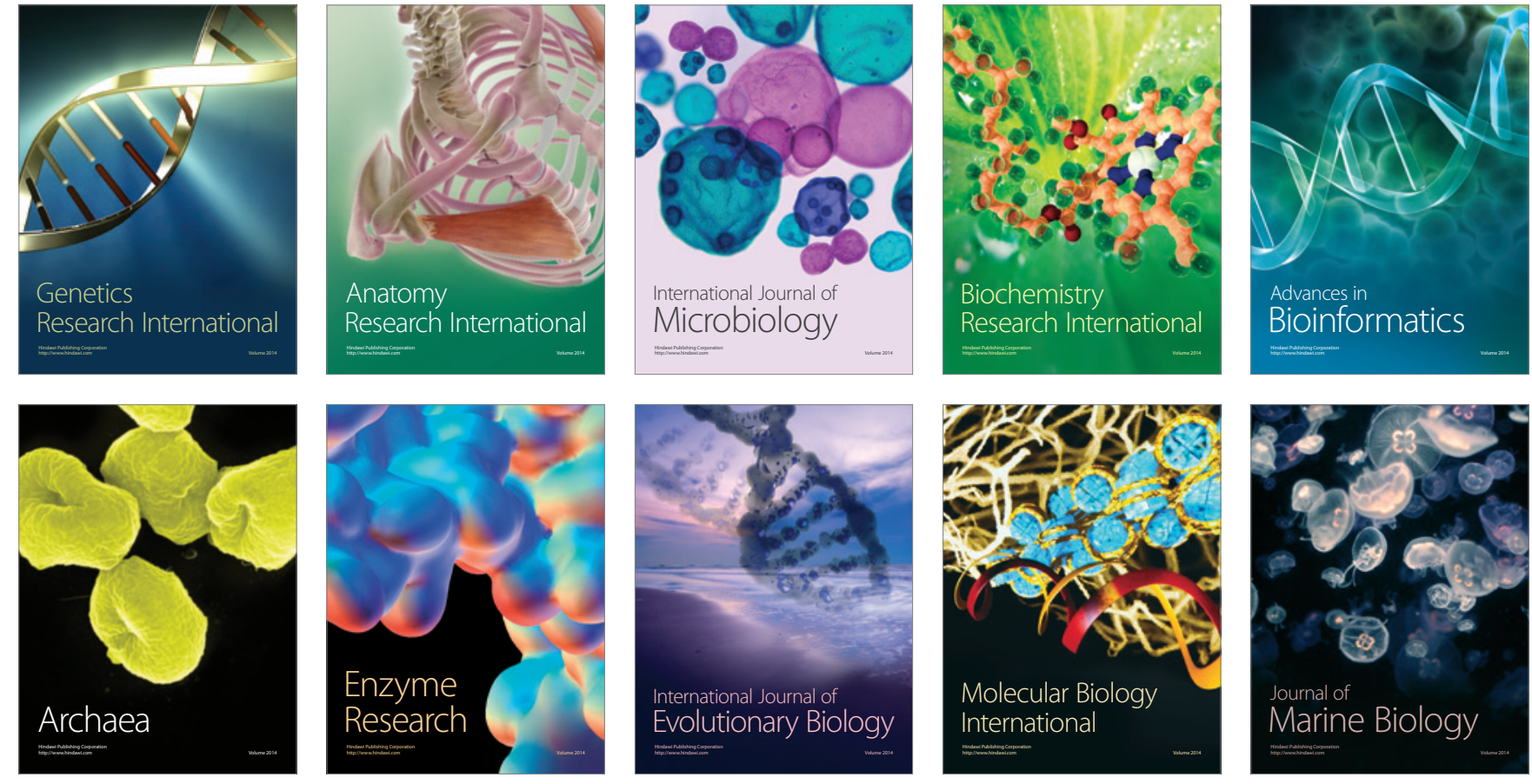